apuntesuniversitarios.upeu.edu.pe

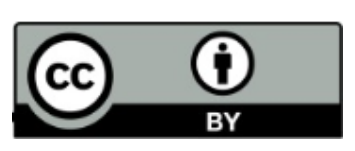

Apuntes Universitarios, 2021: 11(2), abril-junio ISSN:

2304-0335 DOI: https://doi.org/10.17162/au.v11i2.643

\title{
El concepto de la palabra "cultura" en textos antiguos iraníes
}

\author{
The concept of the word "Culture" in Iranian ancient texts
}

\author{
Morteza Tahami ${ }^{1}$,Ali Asghar Rajabi ${ }^{2 a}$ \\ Department of Education, Kharazmi University, Tehran, Iran ${ }^{12}$ \\ D Orcid ID: https://orcid.org/0000-0002-3630-5493 ${ }^{1}$ \\ D Orcid ID: https://orcid.org/0000-0002-0218-26912
}

Recibido: 15 de setiembre de 2020

Aceptado: 05 de enero de 2021

\section{Resumen}

Este estudio analiza el concepto de la palabra "cultura" en los textos antiguos iraníes. La implementación se realiza utilizando los recursos bibliográficos a disposición de los autores. Los hallazgos de la investigación se recopilan de textos antiguos, especialmente los textos del persa medio. La metodología de la investigación tiene un carácter narrativo de citas. Para comprender cualquier fenómeno, es necesario comprender el proceso histórico de ese fenómeno. Dado que la cultura es un elemento esencial en la evolución de una sociedad, un examen de su proceso histórico ayuda a comprender el significado y el significado del término en los textos principales y en la vida iraní. Por tanto, debido a la importancia de la cultura, aquí hemos explorado los significados y conceptos de cultura desde la perspectiva de los textos antiguos. Los resultados muestran que la cultura de la palabra se compone de dos componentes: frā significado ("adelante y arriba"); y hong, de la raíz de sang, que significa "tirar" o "arrastrar y llevar". Como resultado de la educación, los seres humanos adquieren conocimientos y habilidades, y estos conocimientos y habilidades adquiridos también se denominan cultura. Además, en los antiguos textos iraníes, la cultura ha llegado a significar "cortesía."

Palabras clave: Cultura, literatura, Iran, textos antiguos, lengua persa.

\begin{abstract}
This study analyzes the concept of the word "culture" in Iranian ancient texts. The implementation is done using the bibliographical resources available to the authors. The research findings are collected from ancient texts, especially the Middle Persian texts. Research methodology has a narrative-citation nature. To understand any phenomenon, it is necessary to understand the historical process of that phenomenon. Since culture is an essential element in the evolution of a society, an examination of its historical process helps to understand the meaning and meaning of the term in the main texts and in Iranian life. Hence, because of the importance of culture, here we have explored the meanings and concepts of culture from the perspective of ancient texts. Results show that the culture the word is made

a Correspondence-Author E-mail: Aliasgharrajabi@Khu.ac.ir
\end{abstract}


up of two components: frā meaning ("forward and up"); and hong, from the root of sang, meaning "pull" or "drag and carry". As a result of education, human beings acquire knowledge and acquire skills, and these acquired knowledge and skills are also called culture. In addition, in ancient Iranian texts, culture has come to mean politeness.

Keywords: Culture, literature, Iran, ancient texts, Persian language.

\section{Introduction}

Culture is the basis of the excellence of human and society. The key to any success depends on the excellence of culture. A cohesive, unifying and unifying culture creates social harmony. It also contributes to human being's adaptation to the creator and the system of existence and to the environment (Motlagh, 2018). The more culture is adapted to human nature, the stronger, more enduring and effective it will be. The meaning of culture in our country's history has been steady. This is because: First, in our culture, human perfection has been seen in intellectual and spiritual life, and culture has been interpreted for the same purpose, namely the culture of flourishing the true nature and essence of man. Secondly: the concept of transmissions has been mediated in the past, but today, due to scientific and technological advancements, there is no simple and unmediated transmission of culture, which can be a threat to our culture. In order to fight threats, we need to: First, get to know our culture well, and secondly, understand the root causes of the threat (Dinkard, 2013). Here we examine the concept of the term from the perspective of ancient Iranian texts. As far as possible from the ancient texts, the texts in which the word culture came in could be brought into the same text as the translation.

For the other hand, the word "culture" has long been used in written works of Persian language and has been the focus of people's attention. The best way to find the meaning of a word seems to be to see how, and where, and with what language owners the word was common among them. The writings of the remaining books represent the thoughts of their age, when they are examined and guided by the correct meaning of this word and its various instances and contexts and derives its people's perception of it (Thaqafi, 2005); Therefore, to further explore the meanings and meaning of the word culture, we examine the subject from the perspective of the ancient texts of Iran to express its definitions and interpretations based on ancient texts. There is no discussion of culture in the Avestan texts, so what is expressed here is Middle Persian texts. From these sources all the texts that were accessible were reviewed and the texts in which the word culture was used were included in this article. The material is categorized and arranged according to the meaning embodied in the context of the culture. In addition, 
there is a brief analysis of the culture based on the texts. The contents of this article provide further background for the technologist (Mohammadi, 1995).

\section{Research background}

There are numerous writings and compilations on culture, including a few. Shariati defines the two words (culture and civilization) in the book Civilization and Culture, and relates the two words to each other, then to philosophy and philosophy. The history of civilizations has been discussed. Hassan Bonyani, in his book What is the Necessity of Cultural Attachments, defines culture in its present state and outlines its general functions (Nearby, 2014).

In the article "Concepts of Culture in Persian Literature" (Saghafi, 2012), he has explored the term "culture" seeking Persian prose books and exploring the meaning of this word in a pragmatic and primitive way. also explores the subject in terms of Shahnameh, prose books and dictionaries, as well as the origins of the term in ancient texts, And the French have spoken English and various pronunciations of the word in ancient texts (Motlagh, 2018). From the available sources, nothing came from a source that searched for the word culture in Iranian ancient texts in a literal and literal sense. So, we have in this article taken the word culture literally and idiomatically, and bring the same texts in which the culture we will review the application (Saghafi, 2012).

\section{Methodology}

The method of this Social research is analytical. The researcher uses the method of Social research when dealing with a problem that has occurred in the past and ended in the past. In other words, the time frame is closed. The problem can be related to the recent past or the root of the valley of events that It happened a century ago (Naderi and Saif, 2018).

Social research is a systematic and accurate study of the past, and the historian works with great skill on points about an event or a person. Social research is the application of the scientific method to Social issues. This research is in fact a systematic search. In other documents and sources, which contain facts in the field related to the Social researcher's question about the past. Therefore, historical research necessarily deals with events that have taken place before the researcher's decision to study them (Delavar, 2017).

The implementation is done using the resources available in the library. The research findings are collected from ancient texts, especially the Middle Persian texts. Research methodology has a narrative- 
citation nature (Bayani, 2016). In this article, we want to address that the long history of Iran testifies that Iranian identity is natural rather than artificial, Iran has maintained its identity, unity, plurality over time, and against the onslaught of military, political and ... The archer does not descend on the bow and try to adapt them to the scene or through cultural exchange, to adapt them to his cultural digestion. This ability to defend and preserve national identity and historical cohesion derives from rich Iranian culture (Khaleghi, 2010). The product is a workgroup. It links the past to the present. The culture of spiritual capital is a people. After all, culture is a vague word that any group and power can interpret and shape according to their own expense. So, examining culture in terms of authentic ancient texts and its historical process, the primary meaning it clarifies its developments and helps to better understand the status quo. Historical recognition of the meaning of culture, the cornerstone, is for the status quo. Therefore, the research method is based on the presented materials and more knowledge of them.

\section{Results}

The word "culture" consists of two components of the prefix fra or frā, in Sanskrit prá and sattak. From the same root in ancient Persian, we have the words asan and asmān (Kent, 2000), therefore the word is derived from ancient Persian culture. So, "culture” means "pulling up", "pushing”, "someone carrying something heavy". This heaviness in the Persian edat means "knowledge and politeness". The terms frahangestān means "school," and frahangīk, "cultural" and frahangīd "cultural", are made of it (Mackenzie, 1994 \& Wakia, 1968). From the root of the ank in Avesta, the same meanings "apply," such as: pulling a wheel with a horse, pulling a sword from a hoe, pulling a beam from a horse (Purdue, 1977). In this context, "Culture" comes from the word "wisdom" (to measure) and the word "wisdom" came from ancient Persian fra. In the literal sense, culture is the term: "to extract and reveal and reveal, and thus add to, the profoundness of the existence of nation-states or within a community of knowledge and the latent forces and independent mental traits and individual and individual talents. And enriching known and unknown human phenomena and creations (Bakhtiari 1978).

\section{The word culture in ancient texts}

In ancient medieval texts, culture has been used in a number of ways. We have classified these meanings as follows:

\section{Culture in the Meaning of Religion}

Culture has referred to religion as meaning: 1- To the name and praise of the creator of Ormazd who gives all profits. 2-And to all the gods created in Mino and Getty 3-and the culture of cultures - the 
religion of Mazdiseni 4- which is the source of knowledge and recognition; that someone accept this mood and the religion that it is, namely, that it is the culture of the culture (Ashuri, 2017).

\section{Culture in the sense of education}

In this sentence, the meaning of culture is more pronounced in the word "business". Career is the result of skill acquisition and it is through training (Qarib, 2004).

\section{Culture in the sense of knowledge}

Trying to demand a culture of what is the culture of the great and the needy for shelter and the need for arrests and the stigma (a few words from Azhar Mehrspandan). The culture here is not just knowledge, but broader meanings (Ashuri, 2017), for example: to (achieve) in the name of art and culture and know how to benefit from the name of what suffering (s), what means of praise, how to praise and wisdom, how man is not praised in the midst of excuses (Qarib, 2004).

\section{Culture in the sense of school}

Search for the culture of demand, what culture is the seed of knowledge, and the fruit of which wisdom is the guide of both worlds. A person who has good ink is good even if they are not given any education (= culture). A person who has bad ink will still have it even if they are trained a lot. An average person gets better and worse with training. That is, he gets better with good training and gets worse with erroneous training. They are used for sin, as atheists do with the teachings of religion (Ashuri, 2017). Also, bad reason is the result of bad education. Bad habit is the result of bad reason. Bad character is the result of bad habit. Wrong action is the result of bad habits, and wrong doing will make the world more demons (Abolqasemi, 1998).

\section{Culture in the sense of order}

In this case, order is good in all things and punishment is the way to nail it against it (Ashuri, 2017).

\section{Discussion}

The results show that the texts that describe it include two words: academy and elementary school. The word is compounded from the two words frahang and st frn. The term Frahang has been explained previously and stāna means "stand". Astan and Satan (= Middle Persian: istān) have been used 
to make the name of the place (Abolqasemi, 1998). The elementary school is composed of the words Deb and Astan. In Sumerian, $d u b$ means "tablet and line" and is later duppu and tuppu in Akkadian. The word is slowly duplicated to mean "tablet and plate" (Pordwood, 1976). Also, in Sanskrit: lipi and dipi, ancient Persian: dip $i$, and Middle Persian: dibirih, has come. If we take polite from the Persian dab and dip roots, as the Taba'i environment in the article (Journal of Education, No. 9) has meant, the meaning of "polite" with the word "polite." There will be one in the Arabic language and during the Umayyad and Abbasid period, those who raised the children of the nobles, whether princes or other courtiers, were said to be polite (Motlagh, 2018). In the Sassanid era there were teachers of horse riding and shooting of the elders who were part of the Divan Corps. What the people were learning about horse riding and shooting was the failure of the kidnapper. The partisans involved in the killing of Baraz also mentioned a person called "fishy" or "fisherman" and labeled him "polite Alaware" (Mohammadi, 1995) is mentioned in the letter of Moderate Tenserness in the sense of "Teacher of Aswara". According to the Achaemenids, Persians taught their children five to twenty years of age most of all three things: riding, shooting, and honesty (Bayani, 2006).

\section{Conclusion}

According to the results we can say that what has been said about the concepts of culture in ancient texts implies that culture has different meanings. Culture literally means to bring forth, to elevate, to impart. The healing of the mysteries of the human being is made possible through proper education and training. Culture is like a device used for exploration of a mine, and when it comes to the source, it then extracts the material lying in the ground and provides wealth to society. So, culture means that one's inner traits and abilities He went out and added to the spiritual assets of the community. Culture is also the basis of thought and thought, and soothing to the human spirit. Culture is also described in terms of: education, skills, knowledge, (knowledge), education, literature, school, discipline, religion, discipline, and science appropriate to the time needed by society. Expressed in: Martial and Sports Affairs, Music, Astronomy, Culinary, Fruits, Geology, Biology.

As well as other concepts such as respect for virtue, virtue, wisdom, and attributes like this: what you do not know about yourself is good for others. Do not do good. Cleanse good from evil. Avoid sin. Holding a religious ceremony in your time. Culture is also used in the sense of managing social affairs. This is how human beings behave properly through culture and through wisdom and perform their duty 
in the world. Otherwise, wisdom is the result of culture as follows: culture; Knowledge is wisdom, and wisdom is global governance (= the administration of social affairs).

\section{References}

Abolghasemi, M. (1994). Farsi verbs Dari. First chap. Tehran: Phoenix. https://tehransbs.pl/10117

Ardeshir, B. (1999). Bahram Farah Vashi, Second Ch. Tehran: University of Tehran. https://press.ut.ac.ir/

Ashori, D. (2017). Definitions and Concept of Culture, Tehran: Adl publisher. https://www.adresdoon.com/jobshow.php?id=19798

Bayani, S. (2016). History of Ancient Iran, From the Aryans to the Achaemenid Period, Sana publisher, Tehran. https://sanabook.com

Delavar, A. (2017). Theoretical and practical foundations of research in humanities and social sciences. Sixth edition. Tehran: Roshd Publications, new edition. http://www.roshdpress.ir/roshd-books-list

Dinkard, B. (2013). Cultural Studies. Translated by Angel Forgery. First Chart. Tehran, Saba publisher. http://www.sababook.ir/

Dinkard,. (2010). Humanities and Cultural Studies. First Chapter. Tehran, Nab publisher. https://ketabeqom.com/publisherinfo

Dinouri, A. (1967). Foundation of Iranian Culture. News by Sadegh Nashat. First edition, Tehran, Aria publisher. https://www.ketabrah.ir/publisher

Ginio, Ph. (1993). Ardavirov Letter. Translation and Research by Jaleh Amouzgar. First Ch. Tehran, Medal publisher. https://www.adinehbook.com/gp

Kent, R.G. (1953). Old Persian, Gatreh publisher, Second Edition. http://www.nashreghatreh.com/?AspxAutoDetectCookieSupport=1

Khaleghi Motlagh, J. (2018). Three articles: Adib, Musk Seed, Mardegaran, Tehran: Librarian. https://payambooks.com/

Mackenzie, D. N. (1994). Small Pahlavi Language Culture. Translated by Mahshid Mir Fakhraei. Tehran: Humanities and Cultural Studies Institute publisher. http://www.ihcs.ac.ir/fa

Mahmoudi Bakhtiari, A. (1978). Iranian Culture and Civilization, A Look at Mythology, Tehran: Bi Na publisher. https://www.chaponashr.ir/mfpb

Mohammadi, M. (1995). Iranian culture before Islam. Fourth chap. Tehran: Toos publisher. https://toosbook.ir/

Naderi, A., Saif Naraqi, M. (2018). Research methods and how to evaluate it in the humanities (with up to one on educational sciences). nineteen edition. Tehran: Arasbaran Publishing. https://www.jeihoon.net 
Nearby, B. Z. (2014). Sogdian culture. Second chap. Tehran: Farhangan publisher. https://ketabkhanehfarhang.ir/

Pahlavi, A. (1988). Cultural Studies and Research. Translated by Mahshid Mir Fakhraei. First Printing: Tehran. https://ketabkhaneh-farhang.ir/

Pahlavi, T. (1992). Culture. Translated by: Saeed Arian Transcript. First Chart. Tehran: Library of the Islamic Republic of Iran. http://www.nlai.ir/

Pour davood, I. (1976). Ancient Iranian Culture. Third Chap. Tehran: University of Tehran. https://press.ut.ac.ir/

Saghafi, R. (2012). Understanding Culture in Persian Literature. Art \& People Magazine, 1, 35-39. https://iranjournals.nlai.ir/ 